\title{
The Role of Civic Education Teachers in Implementing Multicultural Education in Elementary School Students
}

\author{
Reza Rachmadtullah ${ }^{1, *}$, Harlinda Syofyan ${ }^{2}$, Rasmitadila $^{3}$ \\ ${ }^{1}$ Department of Teacher Education Elementary Schools, Universitas PGRI Adi Buana, Surabaya, Indonesia \\ ${ }^{2}$ Department of Teacher Education Elementary Schools, Universitas Esa Unggul Jakarta, Indonesia \\ ${ }^{3}$ Department of Teacher Education Elementary Schools, Universitas Djuanda, Bogor, Indonesia
}

Received December 2, 2019; Revised January 7, 2020; Accepted January 16, 2020

Copyright $\bigcirc 2020$ by authors, all rights reserved. Authors agree that this article remains permanently open access under the terms of the Creative Commons Attribution License 4.0 International License

\begin{abstract}
This research is based on the background that the state of Indonesia is an archipelago which has various ethnicities, religions, races, groups and so on. These differences have the potential to enrich Indonesia. But on the other hand it can backfire for the Indonesian people who can divide the Indonesian nation. If the diversity possessed by the Indonesian people is not managed properly and correctly, then it can become a source of division within the Indonesian nation. Multicultural awareness in every individual needs to be strengthened. One way is through education, both formal and informal. This study aims to determine the role of civic education teachers in implementing multicultural education to elementary school students. The method used in this study uses a qualitative approach with participants, namely elementary school teachers. The results of this study indicate that the role of civic education teachers in implementing multicultural education in primary schools by instilling tolerance, respect, and mutual respect for differences between people, provides material that is taught containing insights on diversity, events, and how to solve problems. social problems that will be faced by students, citizenship education teachers in building gender sensitivity and implementing anti-discrimination attitudes towards differences in abilities possessed by students. Based on the research findings, the contribution in this research is the role of civic education teachers in implementing multicultural education in elementary schools is needed, because children can recognize the diversity around them, learn to respect each other and respect each other.
\end{abstract}

Keywords Civic Education Teacher, Multicultural, Elementary Education

\section{Introduction}

Multiculturalism, in general, is also a term that refers to a plural society consisting of more than two unequal communities or groups. Hierarchical differences in different classes of social systems are a form of the stratification of multicultural societies [1], [2]. Individual or group differences within the school environment make learning about living together in the many differences that exist. The gap between students in the school environment is also quite clear [3], [4]. Most of them usually play in groups of their respective tribes. This condition shows how important multicultural awareness is in the school environment [5], [6]. Therefore a moderate attitude is needed that requires self-awareness, in the sense of knowing oneself, the nation, its history, and culture. Build awareness that Indonesia is a country with various tribes and cultures. therefore we need to realize that it is very important to develop multiculturalism. This attitude is shown by students merely recognizing the diversity of differences, but also encouraging each to contribute actively to the processes of shared life [6].

Indonesia is a big country with all the cultures and customs inherent in it, the various cultures cannot be denied that it will give birth to a variety of positions views that Indonesia is a country with diverse ethnic, racial cultures and diverse religions. The study of pluralism today is often referred to as the term Multicultural education.

Multicultural education needs to be expanded so that Indonesian people better understand the importance of maintaining harmony among humans, in understanding something must be in full so that what is the majesty of science in multiculturalism can be widened beyond not only limited to appreciating differences more than that of understanding so the importance of maintaining harmony, giving ethics in the opinion of other groups, upholding the principle of humanity and so forth is expected to be able to give glory in a multi-paced country, namely Indonesia.

The term Multiculturalism or Multicultural education in Indonesia found its momentum during the reform era, where freedom of speech was very wide open which in the previous mass was very restrained. It was then that experts began to think about the importance of Multicultural education for a 
diverse Indonesian nation.

Education in Indonesia is legally regulated by providing diversity as a nation. National Education System Law Article 4 Law N0. 20 of 2003, one of his dictums stated that "education is carried out in a democratic and just and non-discriminatory manner by upholding human rights, religious values, cultural values, and national pluralism". This principle shows that the government is very open to implementing multicultural education into the national education curriculum. Multicultural education can train and build the character of students capable of being democratic, humanist, and pluralist in their environment. That way in everyday life students can always be democratic, pluralist, and humanist.

Discussing multiculturalism Indonesia is a country that consists of various ethnic, cultural, ethnic and religious groups so that Indonesia can simply be called a multicultural society [1]. However, on the other hand, the multicultural reality is faced with an urgent need to reconstruct Indonesia's national culture which can become an integrating force that binds all ethnic and cultural diversity. Pluralism is certainly found in every community [7].

Indonesia has a plurality of tribes. This plurality of tribes is one of the characteristics of Indonesian people to be proud of. However, without us realizing that the plurality also holds the potential for conflicts that can threaten the life of the nation and state. This has been proven in conflicts in some regions of Indonesia such as in the Sampit area in Poso, in Aceh or fights that often occur between villages in several parts of Java and student fights between schools (student brawls). To minimize the conflicts that have occurred, the school must instill the values of togetherness, tolerance, and being able to adapt to differences. The education process in this direction can be pursued by multicultural education. Multiculturalism education has been applied since basic education because by applying multicultural education since the age of students in primary school can apply how to respect each other, sincere, and tolerant of the cultural diversity that lives in the midst of a plural society. With the application of multicultural education in elementary schools carried out by civic education teachers, it is hoped that the mental flexibility of the nation is facing the conflict of social conflicts

Education, in order to instill the values of multicultural values of students, will help students understand, accept and respect other people with different ethnic, cultural and personality values [8], [9]. By instilling the spirit of multiculturalism in schools, it will become a medium of training and awareness for the young generation to accept cultural, religious, racial, ethnic and needs differences among others and want to live together peacefully [10], [11]. Basically, a teacher is a major element in achieving an educational goal both formal and non-formal education. The most important role is that teachers are expected to be able to educate their students to be respectful of differences in the learning process at school and to develop multicultural values in everyday life in society. According to law number 14 of 2005 concerning teachers and lecturers, "Teachers are professional educators with the main task of educating, teaching, guiding, directing, training, evaluating and evaluating students in early childhood education through formal channels of basic education and secondary education".

Multicultural education is an educational strategy that is applied to all types of subjects by using cultural differences that exist in students such as ethnic differences in religion, language, gender, social characteristics, race, ability, and age so that the learning process becomes effective and easy [12], [13]. Meanwhile according to [14] multiculturalism education is a set of beliefs and explanations that recognize and assess the importance of cultural and ethnic diversity in the form of lifestyle, social experience, personal identity, educational opportunities of individuals, groups, and countries. Multiculturalism education is an idea, movement, education renewal and educational process whose main purpose is to change the structure of educational institutions so that students both men and women, students with special needs, and students who are members of diverse racial, ethnic and cultural groups. will have the same opportunity to achieve academic achievement in school.

In the learning process, civic education teachers in elementary schools are expected to not only teach but also provide material explanations to students. The teacher does not only design plain lessons (starting from apperception, teaching strategies, and closing [15]-[17]. The teacher is not only busy with the teaching style but the most important thing is that a teacher must be able to create an atmosphere of learning and an active learning process, inspire, motivate, and foster multiculturalism in the context of daily life so that later students are expected to be children who are can accept and respect other people from different ethnic groups and cultures. The role of the teacher is very important in instilling values.

Multicultural Education is the process of planting a way of life respecting, sincere and tolerant of cultural diversity in a plural society [2]. Through the implementation of Multicultural education students are expected to be able to solve problems in accordance with real-life that with differences in culture, race, region, ethnicity and language will respect each other [3].

The application of multicultural education in every subject of citizenship education can be done with the right strategy and in accordance with the regulations of the Ministry of National Education (2010: 9-10) formulating 18 values of the Indonesian nation's character. These values are religious values, honesty, tolerance, discipline, hard work, creative, independent, democratic, curiosity, national spirit, love of the motherland, respect for achievement, friendly or communicative, love peace, love to read, care for the environment, social care, and responsibility.

Multiculturalism is an understanding and perspective that emphasizes the relationship of every human being by seeing 
the existence of each culture and being seen as equal, thus a normative notion of harmony, tolerance, mutual respect for differences and the rights of each culture of a nation. According to Blum the concept of multiculturalism is an understanding, appreciation, and assessment of one's culture, as well as a respect and curiosity about certain ethnic cultures. In other words, multiculturalism is an assessment of other people's cultures not in the sense of agreeing to all aspects of these cultures, but rather trying to see how an indigenous culture expresses values for its own members [4].

According to Banks, (2015) [14] Multicultural education is basically a nation's education program so that multicultural community can participate in realizing an ideal democratic life for their nation, there are five interrelated dimensions in multicultural education, namely: (1). Conten Integration integrates various cultures and groups to illustrate fundamental concepts, generalizations and theories in subjects or disciplines. (2). The knowledge construction process, takes students to understand the cultural implications into a subject. (3). An Equity Pedagogy adapts teaching methods to student learning in order to facilitate student academic achievement that varies in terms of race, culture, gender, or social. (4). Prejudice Reduction, identifying the racial characteristics of students and determining their teaching methods. (5). Train groups to participate in all extra-curricular activities (cultural arts, sports, religion, or other activities) to be able to interact between students and educators (teachers) in creating academic culture. Sutijono [19] proposes a standard of educational competence based on multiculturalism is to produce citizens who can live in harmony with one another regardless of religion, race, language, culture and social, respect each other's rights, provide opportunities for all groups to develop their culture, and increase cooperation between groups for the prosperity of their country.

Cultivating the values of multiculturalism applied by civic education teachers in Elementary Schools is by conducting attitudes to students through education in schools by emphasizing the values that must be instilled in life by means of respecting each other, sincerely tolerant of the diversity of living cultures in the midst of a pluralistic society with fellow students and the community on a daily basis. The inculcation of these values essentially refers to the affective domain (feelings and attitudes), the cognitive domain (rational thinking) and the psychomotor domain (skills). Instilling the values of multiculturalism also develops the character and character of students through the appreciation of the values and beliefs that exist in society.

\section{Method}

This study uses descriptive qualitative research methods because this research is carried out by observing the condition of students to be disclosed. Qualitative research is a process of research and understanding based on methodologies that investigate social phenomena and human problems. In this research, the researcher emphasizes the nature of reality that is built socially, the close relationship between the researcher and the subject under study. Descriptive research is research that seeks to describe a phenomenon, event, event that is happening now. Descriptive research focuses on the actual problem as it is at the time of the research

The subjects of this study were elementary school teachers in Mempawah district, West Kalimantan Province in Indonesia, amounting to 10 teacher respondents who were certified educators. The research will obtain representative data if it uses a method that is able to reveal the data needed. For this reason, in collecting data, researchers use several methods, namely interviews, documentation, and observation.

Data analysis techniques were taken using qualitative data analysis models [20] Where this model is an activity of analyzing qualitative data in an interactive way and takes place continuously until it is complete until the data is saturated. Researchers collect data through observation and interviews, then researchers reduce data by selecting the data needed. Then, the researcher presents the data in narrative form. In data analysis, the thing to do is to draw conclusions. Valid conclusions are accompanied by tangible evidence. The steps of the analysis carried out in qualitative research according to [20] can be seen in the following chart:

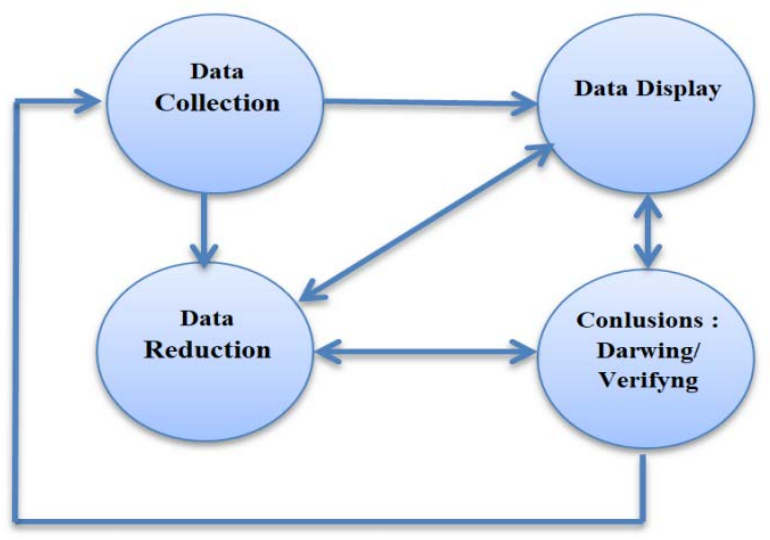

Figure 1. Chart of Qualitative Analysis of Miles and Huberman

Based on the chart above, the explanation of the stages of analysis in this study is as follows (1) Data collection is a process of entering the research environment and conducting data collection. Primary data in the form of observation to see firsthand the atmosphere, circumstances, and reality that occur in the field. Then conduct interviews with key informants and those who support by asking questions. Researchers need to be able to communicate with respondents or informants to be willing to provide answers that are open and correct according to the situation. Secondary data was also obtained from documents and archives and school supporting data. (2) Data reduction, which is to summarize and choose the main things, then focus on the important things, look for the theme of the 
pattern and discard the unused. The data obtained is then reduced will provide a clear picture and make it easier for researchers to collect data and look for it when needed. Data reduction is done by researchers by listening to the results of interviews from research subjects. Interview results that are not in accordance with the study discussion will be discarded. Researchers tidy up the results of observational notes with field notes adjusted to the study discussion. (3) Data display, namely the presentation of information to draw conclusions in data collection. With the presentation of data, the data can be organized and can be arranged in patterns and can be easily understood. (4) Conclusions: Drawing / verifying) It is drawing conclusions from data that has been analyzed. Data collection will end if the researcher can answer the formulated problem then form a discussion to draw conclusions and data presentation.

\section{Results}

The role of the teacher in implementing Multiculturalism Education is a means for safeguarding values that are felt capable of encouraging development and survival in society. In multiculturalism education it is expected that a teacher is required to be professional, but must also be able to instill values such as democracy, humanism and pluralism. By instilling these values students are expected to uphold the principles of morality, discipline, caring, humanistic and honesty in daily behavior. In connection with the implementation of multicultural education in building awareness of students to address the diversity that exists in Indonesia, the results of this study suggest several steps adopted by the teacher as follows:

\subsection{The Teacher's Role Instills Tolerance, Respect and Mutual Respect for Diversity}

The role of teachers in elementary schools always strives to implement multicultural education in learning activities in schools by delivering teaching material on the importance of tolerance, respect and mutual respect for diversity through behaviors that arise and can be classified into forms of behavior related to religious tolerance naturally appear in in the context of the condition of religious diversity in state elementary schools under West Kalimantan. These attitudes and behaviors are a real impact of religious differences and worship practices carried out in the school environment. The behaviors that arise and can be classified into behaviors that are related to tolerance, respect and mutual respect for diversity. These attitudes and behaviors are the real impacts of religious differences and worship practices that are carried out in the school environment.

The environment in which the research is carried out is a multi-ethnic student environment and various other religions and beliefs. the majority of religions embraced by students are Islamic religions but some embrace Protestant, Catholic,
Hindu, and easy religion so the role of the teacher must be able to be democratic, meaning that in every behavior, both the attitude and words are not discriminatory (being fair and not offending) students of different religions. The next step taken by the teacher to realize or foster an attitude of tolerance in students is to implement and understand what tolerance is. Broad tolerance is a human attitude or behavior that does not deviate from the values or norms of religion, law, culture, in which a person respects or respects everything that others do. Tolerance can also be said in terms of socio-cultural and religious contexts which means attitudes and behaviors that prohibit discrimination against different groups or are not acceptable to the majority in a group. Teachers always express high concern for certain events that have to do with religion. And a teacher must be able to explain the core of religious teachings is to create peace and prosperity for all humanity. Dialogue and deliberation are ways of resolving all kinds of problems that are highly recommended by religion and all existing beliefs.

Based on the results of interviews with the three teachers during the learning, the teacher instilled in order to be able to be tolerant, respectful, respectful for living in a diverse environment. As stated "AK (Informant 1)", "BE (Informant 2)", "DE (Informant 3)" follows:

"In our school environment is a diverse environment our students are trained to get used to different lives of beliefs, ethnicity, and ethnicity, but we still teach the importance of having an attitude of tolerance, respect and mutual respect for diversity because of the presence of tolerance, respect, and mutual respect diversity has benefits that can avoid the divisions between religious communities, can strengthen the ties of friendship, the creation of peace in a peaceful and harmonious social life (Informant 1) ".

Based on interviews conducted with informants 2:

"We as teachers who teach in a multi-ethnic environment always apply the importance of tolerance, respect and mutual respect for diversity because we realize that in order to avoid war and division: Learning to respect the opinions of others is an important asset for creating peace. Many battles or divisions occur as a result of attitudes that cannot respect the opinions of others. Tolerating by respecting the opinions of others will lead to a more beautiful life. Tolerance between religions is a real form of respect. The element of religion is important in the eyes of the people. If there is no tolerance, this religious issue is very vulnerable to cause divisions and conflicts. As is currently the case of SARA riots due to lack of tolerance (Informant 2)"

Based on interviews conducted with informants 3 :

Our way as teachers in implementing multiculturalism education is to always implement an attitude of tolerance towards others will cause a sense of affection and also a strong sense of brotherhood (Informant 3).

Based on the results of the interview above, it can be 
concluded that as an effort given by the teacher in the process of implementing multiculturalism education through learning in schools, by instilling good citizenship attitudes, one of them teaches how to tolerate, respect, and respect each other diversity to their students so that they are not consumed by issues which the truth is uncertain. Implanting the tolerance given by the teacher is to be a good example for students by being democratic in every behavior and caring for events related to ethnic, religious and racial differences. In formal education teachers are an important factor in implementing religious tolerance values in the learning process.

\subsection{The Material Taught Contains Insight into Diversity, Events and Social Problems}

The material in learning civic education has taken examples of problems and social events that are in the community. The teacher also conveys the insight of diversity to students. Based on the results of the interview, the material presented took the cases that were taking place and used community environmental examples. As stated by "WA Informant 5" that is in learning to use the surrounding environment and phenomena that occur.

In the delivery of material insight into diversity, events and social problems Teachers train students to solve social problems that occur so that students are able to make decisions and take action related to concepts, issues, and problems related to diversity. The way the teacher trains students in solving social problems can be through debate and problem-solving. When civic education teachers train students in solving social problems through debate and problem-solving. This opinion is supported by the statement "WA Informant 5" which teaches how to overcome social problems through debate activities. Through debate activities, students can think and conclude these problems.

\subsection{The Role of Civic Education Teachers in Building Gender Sensitivity}

In multicultural education, education has a very strategic role to build student awareness about the importance of upholding women's rights and building anti-discrimination attitudes towards women. Therefore, teachers are required to have a role in building students' awareness of gender awareness values and anti-discrimination attitudes towards women in schools by First, teachers must have sufficient insight into gender equality. This insight is important because the teacher is the main figure that becomes the center of attention of students in the class, so it is expected to be able to be fair and not discriminatory towards female and male students. Second, a teacher is required to be able to practice the values of gender justice directly in the classroom or at school. Third, sensitive to gender issues inside and outside the classroom.

Meanwhile, schools also have a very important role in instilling the values of gender equality and justice by First, schools must have and at the same time implement anti-gender discrimination school laws. Secondly, schools must play an active role in providing gender training to all staff including teachers and students so that the inculcation of values on equal rights and anti-gender discrimination attitudes can be carried out effectively. Third, to foster and raise students' awareness about gender equality and anti-discrimination attitudes towards women, the school can hold seminars or other social activities related to the development of gender equality. Fourth, the role of teachers and schools in building attitudes of social care. Teachers and schools have a role to play in developing students' attitudes to care and be critical of all forms of social, economic and political injustice that exist in the surrounding environment and outside the environment. A teacher must have sufficient insight into various kinds of social phenomena that exist in the environment of the students, especially those related to poverty, unemployment, students who cannot continue schooling, corruption, eviction and others. At school or in the classroom, teachers can apply these attitudes by being fair to all students without having to privilege one of them even though their social background is different.

\subsection{The Role of Civic Education Teachers in Elementary School in Building Anti-Discrimination Attitudes towards Differences in Abilities}

In the results of this study, it was found that the teacher as the main driver of student awareness in order to always avoid discriminatory attitudes towards differences in the ability of students both inside and outside the classroom, including also outside school. By giving examples directly to students, students are expected to be able to emulate, apply and build awareness to not take discriminatory actions against those who have different abilities, such as students who stutter or have low memory and so on, so that they can mutual understanding, respect and respect for each other. Likewise, schools must be able to become institutions that build the attitude of students who always respect others who have different abilities by First, making and implementing school rules that emphasize that schools accept "normal" students and those who have the ability different. Second, schools provide special services such as teachers with special skills to handle students who have different abilities and provide special facilities such as special rooms, special seats or other special facilities. Third, schools should provide training for teachers and staff on how to behave and how to deal with students who have different abilities at the school.

Furthermore, in implementing multicultural education it is necessary to provide efforts to foster students' understanding and attitudes so that they always respect, respect and protect the rights of others who have different abilities. And the steps taken by civic education teachers are (1) the teacher has good insight and understanding about the importance of anti-discrimination attitudes towards people who have different abilities. (2) The teacher as the main driver of 
student awareness in order to always avoid discriminatory attitudes is able to practice anti-discrimination discourse directly inside and outside the classroom. (3) The teacher must be responsive to seeing discrimination related to this ability and provide understanding to students that all humans have defects depending on how they can manage these deficiencies to be strengths.

Based on the results of interviews with the three civic education teachers during teacher learning instill in order to be able to behave anti-discrimination towards differences in abilities. As stated "CU: Informant 4" follows:

"... if you say there are already many diverse students with different abilities, automatically they have learned how to respect others. I often motivate students to respect their friends' abilities and respect their friends' opinions even though their friends' opinions are wrong and I teach students to speak well to correct these wrong opinions (Informant 4)".

\section{Discussion}

Based on the findings of the study found that there are several sub that need to be considered about the role of civic education teachers in implementing multicultural education, namely through The teacher's role instills tolerance, respect and mutual respect for diversity, The material taught contains insights into diversity, events, and social problems , The role of civic education teachers in building gender sensitivity, The role of civic education teachers in elementary school in building anti-discrimination attitudes towards differences in abilities according to statement Banks [8] The presence of teachers in the teaching process becomes very important because one of the keys to success in the learning process is not only seen from the aspect of the success of a student getting good grades, but more importantly is the extent to which a teacher can build, instill, and shape the character of multiculturalism as a good citizen, especially in accepting diversity in the surrounding environment. So that students are expected to have the character of tolerance and accept diversity, then the realization of unity in differences in the school environment or social environment. Multiculturalism in this research is to accept diversity and mutual tolerance in the school and community environment. Students instill a multicultural attitude automatically he will realize the differences that are around him and do not make that difference as something that can be questioned, but he will think that this difference is what makes the beauty of the Indonesian state. Students who will be careful writers are students who lack confidence.

Multicultural education as a progressive approach to transforming education which holistically provides criticism and shows the weaknesses, failures and discrimination that occur in the world of education. Therefore, it is necessary to have a strong foundation to build a better multicultural education. The multicultural education paradigm building offered is as follows: (1) Multicultural education is at the heart of creating equality of education for all citizens, (2) Multicultural education is not just about curriculum changes or changes in learning methods, (3) Multicultural education transforms awareness that provides the direction in which the transformation of educational practice must lead to, (4) Experience shows that efforts to narrow the gap in education are misdirected, which actually creates inequality, and (5) Multicultural education aims to do something, namely building bridges between curriculum and character of teachers, pedagogy, climate class and school culture in order to build a vision of a school that upholds equality [21]. Multiculturalism education is a set of beliefs and explanations that recognize and assess the importance of cultural and ethnic diversity in shaping lifestyles, social experiences, personal identities, educational opportunities of individuals, groups and countries [14]. In this sense, there is a recognition that assesses the important aspects of cultural diversity in shaping human behavior.

\section{Conclusions}

The role of civic education teachers in implementing multiculturalism education by applying the importance of tolerance, its importance. building gender sensitivity, building an anti-discrimination attitude towards differences in abilities. If the teacher can carry out multiculturalism education well, the results will give birth to civilization and the building of a tolerant, democratic, benevolent, benevolent society, like to help, tolerance, harmony, beauty and upholding human values. In essence, ideas and designs that are carried out by teachers in implementing multicultural education can create good students and have the character of a sense of unity among nations and nations, preparing students to be good and civil society. Multiculturalism can simply be interpreted as recognition of cultural pluralism. The root of multiculturalism is culture, that is culture seen from its function as guidelines for human life. In context nation building, this multicultural term has been form an ideology called multiculturalism. Multiculturalism is various experiences that shape general perception with respect to age, gender, socioeconomic status, type cultural identity, language, race and need special. Judging from the two meanings above, multicultural education is a conscious effort to develop personalities inside and outside schools that learn about various kinds social status, race, ethnicity, religion in order to be created smart personality in the face issues of cultural diversity

\section{Acknowledgments}

The authors would like to thank all those who have contributed to participation in this study. 


\section{REFERENCES}

[1] O. Agirdag, M. S. Merry, and M. Van Houtte, “Teachers' Understanding of Multicultural Education and the Correlates of Multicultural Content Integration in Flanders,” Educ. Urban Soc., vol. 48, no. 6, pp. 556-582, Jul. 2016.

[2] H. A. R. Tilaar and S. D. Hapsari, Multikulturalisme: Tantangan-tantangan global masa depan dalam transformasi pendidikan nasional. Jakarta: Gramedia Widiasarana Indonesia, 2004.

[3] C. Stokke and L. Lybæk, "Combining intercultural dialogue and critical multiculturalism," Ethnicities, vol. 18, no. 1, pp. 70-85, Feb. 2018.

[4] I. Hill, "Multicultural And International Education: Never The Twain Shall Meet?,” Int. Rev. Educ., vol. 53, no. 3, pp. 245264, Jul. 2007.

[5] R. Vervaet, M. Van Houtte, and P. A. J. Stevens, "Multicultural Teaching in Flemish Secondary Schools: The Role of Ethnic School Composition, Track, and Teachers' Ethnic Prejudice,” Educ. Urban Soc., vol. 50, no. 3, pp. 274 299, Mar. 2018.

[6] S. Ningsih, "The Role of Teachers in Embedding Multicultural Values of State High School 1 Sidomulyo Students [Peran Guru Dalam Menanamkan Nilai nilai multikultural Peserta Didik Sekolah Menengah Atas Negeri 1 Sidomulyo]," Universitas Lampung, 2007.

[7] C.-Y. Hoon, "Multicultural citizenship education in Indonesia: The case of a Chinese Christian school," J. Southeast Asian Stud., vol. 44, no. 3, pp. 490-510, Oct. 2013.

[8] J. A. B. Banks and C. A. McGee, Multicultural Education. Wiley, 2015.

[9] B. Ngo, “Doing 'Diversity’ at Dynamic High: Problems and Possibilities of Multicultural Education in Practice,” Educ. Urban Soc., vol. 42, no. 4, pp. 473-495, May 2010.

[10] D. I. Rubin, "From the Beginning: Creating a Diversity and Multicultural Education Course at Jacksonville State University,” Educ. Urban Soc., vol. 50, no. 8, pp. 727-746, Nov. 2018.

[11] H. Parkhouse, C. Y. Lu, and V. R. Massaro, "Multicultural Education Professional Development: A Review of the Literature,” Rev. Educ. Res., vol. 89, no. 3, pp. 416-458, Jun. 2019.

[12] M. Sahal, A. A. Musadad, and M. Akhyar, "Tolerance in Multicultural Education: A Theoretical Concept,” Int. J. Multicult. Multireligious Underst., vol. 5, no. 4, p. 115, May 2018.

[13] B. Tonbuloglu, D. Aslan, and H. Aydin, “Teachers' Awareness of Multicultural Education and Diversity in School Settings,” Eurasian J. Educ. Res., vol. 16, no. 64, pp. $1-28,2016$.

[14] J. A. B. Banks, "Multicultural education, school reform, and educational equality," in Opening the doors to opportunity for all: Setting a research agenda for the future, 2015, pp. 54-63.

[15] H. A. Alismail, "Multicultural Education: Teachers' Perceptions and Preparation,” J. Educ. Pract., vol. 7, no. 11, pp. 139-146, 2016.
[16] A. A. Wahab and Sapriya, Teori \& Landasan Pendidikan Kewarganegaraan. Bandung: Alfabeta, 2011.

[17] K. Komalasari and Sapriya, "Living Values Education in Teaching Materials to Develop Students' Civic Disposition,” New Educ. Rev., vol. 44, pp. 107-124, 2016.

[18] L. Blum, "Recognition and Multiculturalism in Education,” J. Philos. Educ., vol. 35, no. 4, pp. 539-559, Nov. 2001.

[19] Sutijono, "Multicultural Education in Indonesia: An Alternative for National Education in Global Era," SOSIOHUMANIKA J. Pendidik. Sains Sos. dan Kemanus., vol. 3, no. 1, pp. 53-66, 2010.

[20] M. B. Miles and M. Huberman, The qualitative researcher's companion. Sage Publication, 2002.

[21] Zamroni, “Civic Education di Perguruan Tinggi: Urgensi dan Metodologi” in Warta PTM, Edisi I Tahun XVI. Yogyakarta: Majelis Diktilitbang PP Muhammadiyah., 2001. 